Piotr Sarnowski* iD https://orcid.org/0000-0001-6056-8237

Uniwersytet Kardynała Stefana Wyszyńskiego w Warszawie

e-mail: ps.waw@wp.pl

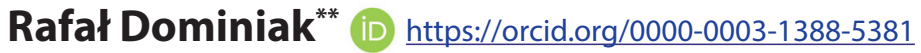 \\ Akademia Humanistyczno-Ekonomiczna w Łodzi \\ e-mail:dominiak.r@gmail.com
}

https://doi.org/10.25312/2083-2923.19/2021_02psrd

\title{
Wycofanie społeczne $\mathbf{w}$ dobie pandemii Covid-19: stary problem - nowe ofiary
}

\begin{abstract}
Streszczenie: Hikikomori, czyli syndrom wycofania społecznego to stary problem, który w obliczu pandemii Covid-19 przybrał na sile. Powszechna izolacja, zdalne nauczanie czy też dystans społeczny to niektóre czynniki zwiększające szansę na rozwój hikikomori. Artykuł opisuje genezę wycofania społecznego, jego możliwe przyczyny, w tym wpływ technologii i relacji rodzinnych na powstawanie hikikomori. Omówione zostanie również badanie lęków społecznych, których koncentracja jest jednym z objawów wycofania społecznego.
\end{abstract}

Słowa kluczowe: hikikomori, Covid-19, samotność, Polska, Japonia, rodzina, uczucia

\footnotetext{
* Piotr Sarnowski - magister, certyfikowany specjalista psychoterapii uzależnień i współuzależnienia, trener grupowy, pedagog resocjalizacji. Pracuje metodą psychodramy oraz ustawień systemowych. Były przewodniczący komisji rozwiązywania problemów alkoholowych w Milanówku. Były wykładowca na Uniwersytecie Kardynała Stefana Wyszyńskiego w Warszawie. Działa na rzecz niepełnosprawnych i bezdomnych. Nominowany do półfinału XVII edycji konkursu „Człowiek bez granic" (2019) za bezinteresowną pracę na rzecz drugiego człowieka. Jest w trakcie pisania pracy doktoranckiej.

** Rafał Dominiak - technik farmaceutyczny z piętnastoletnim doświadczeniem, posiada wachlarz farmaceutycznych certyfikatów szkoleniowych, między innymi z obsługi trudnego pacjenta. Od 2020 roku strażnik miejski. Student Akademii Humanistyczno-Ekonomicznej w Łodzi - kierunek bezpieczeństwo wewnętrzne. Zainteresowania: psychologia, genealogia, socjologia. W chwili obecnej bez znaczącego dorobku naukowego, jednak zawsze ciekawy świata i ciągle poszukujący.
} 
Epidemie chorób zakaźnych w historii ludzkości nigdy nie były czymś nadzwyczajnym. Ich pojawieniu się towarzyszyły różne reakcje społeczeństw, które dostosowywały swoje postępowanie do danej sytuacji epidemicznej. Również dziś narody wprowadzają różne sposoby walki z pandemią. Bez wątpienia lata dwudzieste XXI wieku zapiszą się w historii pod znakiem wirusa Sars-CoV-2. Po ponad roku od wybuchu epidemii wiemy już, że oprócz skutków fizycznych pandemia niesie ze sobą również szerokie spektrum zaburzeń psychicznych. Powszechna izolacja społeczna stosowana w profilaktyce zakażeń pobudza między innymi rozwój syndromu hikikomori ${ }^{1}$, określanego także mianem wycofania społecznego. Zaburzenie to znane jest na świecie od niemal trzydziestu lat. Pierwsze przypadki zdiagnozowano w Japonii, jednak z czasem syndrom hikikomori rozprzestrzenił się po całym świecie. Ekspansja wycofania społecznego początkowo dotyczyła krajów o systemach edukacji zbliżonych do japońskiego - Korei Południowej, Chin, Singapuru, Hongkongu czy Tajwanu². Potem jednak zjawisko to zaczęło dotykać również kraje o filozofii odmiennej od konfucjanizmu. Przypadki hikikomori opisano już między innymi w Kanadzie, USA i większości krajów europejskich ${ }^{3}$. W 2001 roku psychiatra Marek Krzystanek zdiagnozował pierwszy przypadek hikikomori w Polsce ${ }^{4}$. W jego rozwoju duże znaczenie mają dwa czynniki: wzrost zamożności społeczeństw oraz ich powszechna cyfryzacja. Stwierdzenie to potwierdzane jest przez brak wycofania społecznego w społecznościach rozwijających się i „technologicznie zacofanych” - ciężko bowiem o powszechność hikikomori chociażby wśród rdzennych ludów Afryki czy koczowniczych plemion Mongolii ${ }^{5}$.

W artykule tym opisujemy, czym jest syndrom hikikomori, jego genezę oraz wpływ pandemii koronawirusa na rozwój wycofania społecznego. Nasze wywody są rozwinięciem krótkiego tekstu pt. Wirus samotności i wyobcowania ${ }^{6}$ oraz projektu studenckiego o nazwie Samotność: stary problem - nowe ofiary ${ }^{7}$. Przedstawiamy również wyniki badania poziomu lęków społecznych i ściśle z nimi związanych zachowań unikowych. Wyniki badania pozwolą na zobrazowanie skali lęków mających bezpośredni wpływ na powstawanie wielu przypadłości o podłożu psychologicznym, w tym

${ }^{1}$ J. Heitzman, Wplyw pandemii COVID-19 na zdrowie psychiczne, „Psychiatria Polska” 2020, nr 2(54), s. 188.

${ }^{2}$ W. Miksza, Teatr jednego aktora i czterech ścian, „Interdyscyplinarne Konteksty Pedagogiki Specjalnej" 2013, nr 2, s. 234.

3 Tamże, s. 234.

${ }^{4}$ M. Krzystanek, Hikikomori. Dzieci internetu, „Psychiatra. Pismo dla praktyków” 2020, nr 1(28), s. 26.

${ }^{5}$ B. Szluz, „Hikikomori” - o problemie wycofania społecznego młodych ludzi, „Seminare” 2018, nr 1(39), s. 84.

${ }^{6}$ P. Sarnowski, Wirus samotności i wyobcowania, Sarnowski Behawioralnie, 2018, https://sarnowskibehawioralnie.wordpress.com/2018/03/02/hikikomori/ [dostęp: 23.07.2021].

${ }^{7}$ K. Ostrowska, W. Gieros, M. Dubieniecki, A. Pośpiech, J. Ratajczyk, R. Dominiak, Samotność: stary problem - nowe ofiary, 2021, Samotność: stary problem - nowe ofiary. - Ankieta „lęki społeczne" (google.com) [dostęp: 23.07.2021]. 
hikikomori. Jest to temat istotny, gdyż nastolatki i młodzi ludzie do około 30. roku życia są na etapie ciągłego budowania swojej sfery uczuć. Niestety współcześni rodzice $\mathrm{w}$ pogoni za pieniądzem zapominają o potrzebach emocjonalnych i psychicznych swoich pociech. W efekcie na początku swego dorosłego życia, kiedy najbardziej potrzebują pomocy i towarzystwa innych, często zostają same z własnymi problemami. A samotność nie jest przyjemna, gdyż jako ludzie jesteśmy zaprogramowani na tworzenie więzi. My, Polacy, zawsze byliśmy bardzo ukształtowani w budowaniu relacji społecznych. Niestety z czasem coraz bardziej to się zmienia. Rozwody, samotne rodzicielstwo, związki patchworkowe, śmierć bliskiej osoby, brak akceptacji, porzucenie przez sympatię, odrzucenie przez otoczenie - to czynniki niezwykle mocno wpływające na zachowanie młodego człowieka. Jednak bez wątpienia największy wpływ na rozwój człowieka ma jego dom rodzinny ${ }^{8}$. Budując własne relacje z otoczeniem, dziecko osiągające dorosłość najczęściej modeluje zachowania zaobserwowane w rodzinnym domu. Często ucieka w samotność, bo inaczej nie umie. Dlatego tak ważna jest więź z rodzicami - im jest większa, tym młody człowiek czuje się bezpieczniejszy. Dzięki temu już jako osoba dorosła jest w stanie właściwie modelować własne relacje i wyrażać swe uczucia. Z tego względu niniejszy artykuł ma na celu przede wszystkim przybliżenie czytelnikom syndromu wycofania społecznego oraz czynników prowadzących do jego rozwoju.

Termin shakaiteki hikikomori ukuł japoński psycholog Tamaki Saitõ. Jest to zwrot utworzony z zestawienia japońskiego przymiotnika shakaiteki tłumaczonego jako społeczny, z połączeniem czasownika hiku (wycofywać się, rezygnować, odchodzić) z czasownikiem kumoru (być w zamku i chronić się, pozostać $w$ świątyni i modlić się, wejść i ukryć się, być w środku i nie wychodzić). Dosłownie tłumaczy się całość jako wycofanie społeczne. Tamaki Saitõ po raz pierwszy opisał hikikomori w 1998 roku w książce Hikikomori. Adolescence without End. Według Saitõ „jest to stan, w którym człowiek przebywa cały czas we własnym domu i nie uczestniczy w społeczeństwie przez minimum sześć miesięcy. Przy tym nie można zdiagnozować choroby

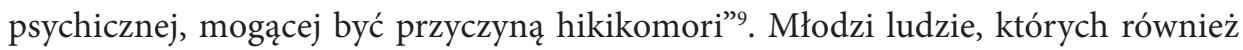
określa się tym mianem, wykazują brak zaangażowania w życie społeczne i zdecydowaną awersję do przebywania w społeczeństwie. Angażują się natomiast w dużym stopniu w wirtualne życie, kontaktując się głównie przez telefon oraz komunikatory internetowe, godzinami surfując w sieci czy grając w rozmaite gry ${ }^{10}$. Wszystko to jest dla nich zamiennikiem realnego kontaktu z rówieśnikami, ze społeczeństwem, z ro-

${ }^{8}$ M. Wisłocka, Sztuka kochania, Wydawnictwo Agora, Warszawa 2016, s. 30-31.

9 T. Saitõ, Hikikomori. Adolescence without End, University of Minnesota Press, Minneapolis 2013, s. 24.

${ }^{10}$ B. Szluz, dz. cyt., s. 86. 
dziną. Szacuje się, że problem ten dotyka od pół do jednego miliona młodych ludzi w samej Japonii ${ }^{11}$.

Genezy hikikomori upatruje się w zmianie modelu rodziny japońskiej, której do wybuchu drugiej wojny światowej filarem był ojciec. Dalej w rodzinnej hierarchii stali: najstarszy syn, potem dopiero żona i pozostali członkowie rodziny ${ }^{12}$. Od rodziców wymagano właściwego wychowywania dzieci, a od dzieci - szacunku do rodziców oraz bezwarunkowego posłuszeństwa wobec nich ${ }^{13}$. Pierworodny syn obdarzony był największymi przywilejami i jeszcze większymi obowiązkami. To on był wzorem dla całej rodziny, on przejmował opiekę nad starzejącymi się rodzicami, on też dziedziczył ich majątek i miał pierwszeństwo na drodze do wykształcenia ${ }^{14}$. Natomiast po drugiej wojnie światowej życie japońskiego społeczeństwa oparło się na idei wzrostu gospodarczego. Ojciec jako głowa rodziny zajął się pracą zarobkową - w firmie zaczął spędzać więcej czasu niż w domu, a życie rodzinne przegrywało z pracą. Praktycznie rola ojca sprowadzała się tylko do kwestii ekonomicznych, za to wzrastała pozycja matki ${ }^{15}$. Wzmocniły się jej relacje z dziećmi - głównie z najstarszym synem. Niejednokrotnie jest to forma ścisłej symbiozy: dziecko bezwarunkowo poddaje się opiece matki, która w zamian dąży do spełnienia wszelakich pragnień swego dziecka ${ }^{16}$. Warunkiem jest tu obustronna akceptacja wzajemnych relacji pomiędzy matką a dzieckiem. Tamaki Saitõ źródeł wycofania społecznego dopatruje się we wspomnianych powyżej relacjach matka-dziecko, a w szczególności matka-syn. Nadopiekuńczy rodzic, który wyręcza swoje dziecko w rozwiązywaniu problemów, nieświadomie doprowadza do tego, że młody człowiek nie może nauczyć się samodzielności. Taki nastolatek w konfrontacji z poważnymi życiowymi trudnościami łatwo wpada w nawyk uciekania od problemów, zaś najbezpieczniejszą kryjówką staje się jego własny pokój. Bywa, że i rodzice są współuzależnieni. Hikikomori bowiem często występuje w rodzinach, które tak naprawdę nie robią nic, aby pomóc swojemu dziecku. Swą „pomoc” sprowadzają do stawiania posiłków pod drzwiami pokoju wycofanego społecznie dziecka. Wszystkie te relacje wpisują się w amae - swego rodzaju doktrynę opisującą system wzajemnych relacji pomiędzy członkami społeczeństwa japońskiego.

Koncepcję amae przedstawił w latach siedemdziesiątych XX wieku japoński psychiatra Takeo Doi. Amae wywodzi się od czasownika amaeru oznaczającego: „zakła-

${ }^{11}$ J.K. Puchalska, Hikikomori - więzień $z$ wyboru, „Maska - magazyn antropologiczno-społeczno-kulturowy" 2010, nr 9, s. 156.

${ }_{12}$ J. Splisgart, Przemiany modelu rodziny a sytuacja ludzi starszych w Japonii u progu XXI wieku, „Gdańskie Studia Azji Wschodniej” 2017, nr 11, s. 139.

${ }^{13}$ K. Kalita, Psychospołeczne wymiary „wycofania społecznego” na przykładzie Japonii, „Zeszyty Naukowe WSOWL” 2013, nr 1(167), s. 72.

${ }^{14}$ J. Splisgart, dz. cyt., s. 140.

${ }^{15}$ K. Kalita, dz. cyt., s. 72.

${ }_{16}$ R. Orzechowski, Analiza dysfunkcji występujacych w rodzinie japońskiej na przykładzie hikikomori i syndromu męża na emeryturze (RHS), „Tematy z Szewskiej” 2017, nr 2(19), s. 48. 
danie, że dana osoba będzie nam życzliwa oraz poleganie na tej życzliwości” ${ }^{17}$. Amae wyznacza głębię wzajemnych relacji pomiędzy członkami japońskiego społeczeństwa bez względu na ich hierarchiczną zależność. Można ją zaobserwować między innymi w relacjach między członkami korporacji, między pacjentem a lekarzem czy też w relacjach matki z dzieckiem ${ }^{18}$. Brak amae jest według japońskich psychologów istotnym czynnikiem warunkującym wystąpienie hikikomori ${ }^{19}$. Paradoksalnie amae może być też przyczyną jego powstania, gdyż pozwala na akceptację największych nawet odstępstw od przyjętych norm społecznych. Charakterystyczne jest tutaj utrzymywanie problemu w ścisłym gronie najbliższych, gdyż dla rodziny temat ten jest bardzo wstydliwy, wręcz tabuizowany ${ }^{20}$.

Zależność znaną w Japonii pod nazwą amae opisał również Erich Fromm w swoim dziele $O$ sztuce miłości: „Nic nie musisz zrobić, żeby być kochanym - miłość matki nie jest obwarowana żadnym warunkiem. [...] Ale fakt, że miłość macierzyńska nie jest niczym uwarunkowana, ma negatywną stronę. Na tę miłość nie tylko nie trzeba zasługiwać - ale także nie można jej zdobyć, wywołać ani nią kierować. [...] Nie mogę uczynić nic, aby ją zrodzić"21. Tym samym potwierdza się teza o ambiwalentnej naturze amae - koncepcji, która udowadnia niebywały wpływ relacji rodzinnych na rozwój młodego człowieka. Bowiem to rodzina jest podstawową jednostką życia społecznego pełniącą funkcje socjalizujące, wychowawcze i emocjonalne. Oprócz tego rodzina powinna zapewniać ochronę i byt wszystkim jej członkom ${ }^{22}$. Zadania te spoczywają jednak na obojgu rodzicach. Brak lub długotrwała nieobecność któregokolwiek z rodziców znacząco wpływa na rozwój emocjonalny dziecka ${ }^{23}$. Dostrzegała to między innymi Michalina Wisłocka, która w Sztuce kochania pisała: „przy założeniu, że witamina M, czyli miłość matki, jest tak niezbędna do życia, każda separacja matki od dziecka, szczególnie małego, staje się dla niego wielkim dramatem. W społeczeństwach cywilizowanych separacja ta obejmuje coraz wcześniejszy okres życia dziecka. [...] I tak do wieku szesnastu-osiemnastu lat kontakt z rodzicami, głównie z matką, redukuje się w najlepszym wypadku do dwóch-trzech godzin dziennie. Ponadto rodzice nieuświadamiający sobie wartości tych kilku godzin dla prawidłowego rozwoju i dojrzewania sfery uczuciowej, a nawet fizycznej i psychicznej dziecka, lekceważą te możliwości kontaktu. [...] Ojciec, który zarabia na dom, jest prawie w ogóle nieuchwytny. Robimy wszystko dla osiągnięcia dóbr materialnych i statusu życiowego,

17 T. Doi, Amae: A Key Concept for Understanding Japanese Personality Structure, [w:] R.K. Beardsley, R.J. Smith (red.), Japanese Culture. Its Development and Characteristics, Methuen \& Company, Londyn 2004, s. 132.

${ }_{18}$ R. Orzechowski, dz. cyt., s. 48.

19 T. Doi, dz. cyt., s. 47.

${ }^{20}$ J.K. Puchalska, dz. cyt., s. 157.

${ }^{21}$ E. Fromm, O sztuce miłości, Dom Wydawniczy Rebis, Poznań 2013, s. 52.

${ }^{22}$ R. Orzechowski, dz. cyt., s. 46.

${ }_{23}$ S. Rydz, Psychologiczne skutki samotnego rodzicielstwa, [w:] I. Janicka (red.), Rodzice i dzieci w różnych systemach rodzinnych, Oficyna Wydawnicza „Impuls”, Kraków 2010, s. 160. 
natomiast prawie nic dla przyszłego rozwoju naszych dzieci”24. Zarówno Wisłocka, jak i Fromm dostrzegają tu niebagatelny wpływ obojga rodziców na budowanie właściwych relacji w dorosłym życiu ich dzieci. Wisłocka opisuje rozwój uczuciowości następująco: „następnym etapem rozwoju uczuciowości dziecka, które wychodzi z ciepłego gniazda miłości macierzyńskiej w wieku lat sześciu lub siedmiu, jest rozwijający się w tym okresie kontakt uczuciowy z ojcem i rodzące się więzy przyjaźni $\mathrm{z}$ rówieśnikami w szkole. Miłość ojcowska ma już inny charakter niż miłość matki, nie polega bowiem na dawaniu stale i bez rachunku, jest natomiast miłością za coś, miłością, na którą trzeba zasłużyć” ${ }^{25}$. Słowa te idealnie uzupełnia Erich Fromm: „nic więc dziwnego, że wszyscy tęsknimy gorąco do miłości macierzyńskiej i jako dzieci, i jako dorośli. Matka jest domem, z którego wychodzimy, jest naturą, glebą, oceanem; ojciec [...] jest tym, który uczy dziecko, tym, który wskazuje mu drogę w świat. [...] W obwarowanej warunkami miłości ojcowskiej odnajdujemy tak samo, jak w niczym nieuwarunkowanej miłości macierzyńskiej, aspekt negatywny i pozytywny. Tym negatywnym aspektem jest fakt, że na miłość ojcowską trzeba zasłużyć, że można ją utracić, jeżeli nie spełni się oczekiwań. [...] Ale pozytywna strona tej miłości jest również ważna. Jeżeli miłość ojca uzależniona jest od jakichś warunków, mogę coś zrobić, aby ją zdobyć, mogę na nią zapracować; miłość ojca nie leży, tak jak miłość macierzyńska, poza zasięgiem mojej kontroli”26. Patrząc spojrzeniem tych dwojga badaczy, należy stwierdzić następujący fakt: każda dysfunkcja rodziny ma niebagatelny wpływ na zdrowie psychiczne jej członków, co wyraźnie widać na przykładzie Japonii. Rozbicie tradycyjnego modelu rodziny, nacisk na rozwój gospodarczy kraju oraz zmiana modelu edukacji znacząco wpłynęły na uwarunkowania psychospołeczne w Japonii. Przemodelowanie społeczeństwa na zdobywanie kompetencji za wszelką cenę oraz silne współzawodnictwo zarówno szkolne, jak i zawodowe wywołało dysfunkcje zachowań społecznych wśród Japończyków ${ }^{27}$. Młodzieży zabrakło czasu i miejsca na realizację swoich potrzeb, co negatywnie wpłynęło na zdolności do budowania zwyczajowych relacji międzyludzkich. Jednym ze sposobów radzenia sobie z wszechobecnym napięciem okazało się wycofanie społeczne, które z czasem zaczęło przyjmować postać chorobliwą ${ }^{28}$. Skomplikowane podłoże wycofania społecznego nie pozwala zidentyfikować podstawowych przyczyn jego powstania. Japończycy specjalizujący się w badaniu i leczeniu hikikomori sugerują, iż na genezę wycofania społecznego mogą mieć wpływ takie czynniki, jak: rozwój gospodarczy, budowa systemu edukacji, presja sukcesu i wszelkiego rodzaju zmiany w strukturze rodziny ${ }^{29}$. Nie ma jednak jedno-

24 M. Wisłocka, dz. cyt., s. 28.

25 Tamże, s. 29.

26 E. Fromm, dz. cyt., s. 54-56.

27 N. Kawakami, M. Umeda, Association of childhood family environments with the risk of social withdrawal (hikikomori) in the community population in Japan, "Psychiatry and Clinical Neurosciences" 2012, No. 66(2), s. 126.

28 B. Szluz, dz. cyt., s. 85.

${ }^{29}$ K. Kalita, dz. cyt., s. 77-78. 
znacznej odpowiedzi na pytanie o etiologię tegoż zjawiska. Równie dobrze mogą to być zarówno problemy rodzinne, szkolne, jak i uzależnienie od internetu i wszelkich e-czynności ${ }^{30}$. Na razie wiadomo, że hikikomori jest formą ucieczki od wymagającej rzeczywistości ${ }^{31}$.

Ekspansja hikikomori poza kraje opierające się na filozofii Konfucjusza może jednak sugerować, iż problem ten nie jest zależny wyłącznie od mentalności danego społeczeństwa, lecz opiera się na uniwersalnych czynnikach środowiskowych i psychospołecznych występujących także w krajach o odmiennej filozofii życiowej ${ }^{32}$. Nie ulega też wątpliwości, że wraz z rozwojem internetu, cyfryzacji społeczeństw i ich uprzemysłowienia problem hikikomori zaczął rozprzestrzeniać się po świecie, dotykając coraz większej liczby krajów ${ }^{33}$, w tym Polski ${ }^{34}$. W naszym kraju duży problem stanowi postawienie prawidłowej diagnozy, a tym samym określenie skali tego zjawiska w polskim społeczeństwie. Przede wszystkim należy zauważyć, że hikikomori jako takie chorobą nie jest - należy je rozpatrywać bardziej w kategorii zjawiska społecznego ${ }^{35}$. Wszystkie zaburzenia towarzyszące mu określa się mianem wtórnych ${ }^{36}$. Jednak rodzice, widząc swoje dziecko zamknięte w czterech ścianach całymi dniami, zaczynają doszukiwać się u niego choroby psychicznej. Długotrwałe życie poza obszarem społecznym, prowadzenie specyficznego trybu życia u części tych dzieci może, lecz nie musi prowadzić do powstania zaburzeń i chorób psychicznych ${ }^{37}$. Dlatego tak ważna jest prawidłowa diagnoza. Błędna terapia daje bowiem skutek odwrotny: pacjent zaczyna odczuwać jeszcze większy strach przed wychodzeniem ze swego pokoju. W efekcie dobrowolnie zamyka się w więzieniu własnego umysłu, gdzie więzieniem jest jego pokój, a strażnikiem jest choroba, która objawia się wycofaniem społecznym. I chociaż w przeciwieństwie do skazańca osoba wycofana społecznie może w dowolnym momencie opuścić swój pokój, to najczęściej tego nie czyni powstrzymywana przez widmo problemów realnego świata. To sprawia, że wycofana osoba staje się więźniem samego siebie - łatwiej jest jej schować się za komputerem i tam budować swój świat. Stąd wniosek, iż wycofanie społeczne jest analogią do więzienia. W obu przypadkach człowiek jest odizolowany od społeczeństwa. Każdy tworzy relacje w grupie, w której przebywa. Dostosowuje się, zyskuje pewien status, którego na zewnątrz nie posiada. Zarówno wycofanie społeczne, jak i pobyt w więzieniu psychicznie zmienia człowieka. W obu przypadkach powrót do społeczeństwa wymaga odpowiedniej resocjalizacji podjętej jeszcze w trakcie izolacji. A i tak tylko co drugi

\footnotetext{
${ }^{30}$ M. Krzystanek, dz. cyt., s. 27.

31 J.K. Puchalska, dz. cyt., s. 159-162.

32 R. Orzechowski, dz. cyt., s. 56-57.

33 M. Krzystanek, dz. cyt., s. 26-29.

34 Tamże, s. 26-29.

35 J.K. Puchalska, dz. cyt., s. 156.

36 K. Kalita, dz. cyt., s. 75.

37 B. Szluz, dz. cyt., s. 84-85.
} 
skazany będzie potrafił dostosować się do świata zewnętrznego ${ }^{38}$. Reszta, prędzej czy później, wróci w mury więzienia, do świata, który zna, gdzie ma spokój i własną pozycję w grupie. Podobnie jest u osób społecznie wycofanych - nie zawsze potrafią się przystosować do normalnego życia w społeczeństwie. Dlatego w rozpoznaniu wycofania społecznego niezwykle istotne są początkowe symptomy, na które należy zwrócić szczególną uwagę. Według Saitõ zalicza się do nich:

- skrajna izolacja społeczna trwająca co najmniej sześć miesięcy,

- unikanie kontaktów międzyludzkich,

- odczuwanie lęków społecznych o znacznym natężeniu,

- odwrócony rytm dobowy z przewagą aktywności nocnej,

- przewaga takich aktywności, jak gry komputerowe, oglądanie telewizji lub surfowanie $\mathrm{w}$ internecie,

- zarzucenie działań wymagających bezpośrednich kontaktów międzyludzkich (szkoła, praca itp.).

Problemy pojawiają się, gdy młodzi ludzie przestają chodzić do szkoły, nie wychodzą ze znajomymi, nie jedzą wspólnych posiłków z rodziną. Początkowo chcą mieć odrobinę prywatności i pobyć przez chwilę samemu. Rodzice starają się to uszanować, jednak wbrew pozorom niezwykle łatwo przegapić ten moment, kiedy następuje odcięcie od otoczenia. Gdy pojawiają się lęki społeczne, poczucie osaczenia i inne zaburzenia, zagubiony w dzisiejszym świecie młody człowiek buduje pewne oddzielenie. Opiekunowie zajęci pracą i własnymi obowiązkami niejednokrotnie nie dostrzegają problemów swego dziecka i z czasem dochodzi do sytuacji, gdy młody człowiek przestaje opuszczać swój pokój i nie utrzymuje kontaktów nawet z rodziną. Jeżeli już nawiązuje jakiekolwiek relacje, to w większości w formie zdalnej. Jednym ze źródeł, które powoduje, że wycofani chowają się za komputerem, może też być presja sukcesu i wczesne ustalenie ścieżki zawodowej, co wpływa na psychikę dziecka, które nie potrafi sobie poradzić $z$ wygórowanymi wymaganiami otoczenia ${ }^{39}$. W konsekwencji w życie młodych ludzi wkracza spory stres i niepokój, poczucie zagubienia i osamotnienia, które w skrajnych przypadkach przeradzają się w syndrom hikikomori.

Zjawisko to dotyczy głównie osób do około 30. roku życia. Są to osoby obeznane $\mathrm{z}$ technologią, pochodzące najczęściej z zamożnych rodzin. $\mathrm{W}$ takich rodzinach pogoń za pieniądzem odsuwa dziecko na dalszy plan. Rodzice zajęci zarabianiem nie dostrzegają problemów dziecka, zapominają o jego potrzebach emocjonalnych i psychicznych, a więź emocjonalna pomiędzy rodzicami a dziećmi ulega rozkładowi. Pomocy w rozwiązaniu swoich problemów dzieci szukają wśród rówieśników lub w internecie. W efekcie może to prowadzić do sytuacji, że młody człowiek przestaje opuszczać swój pokój i nie utrzymuje kontaktów nawet z rodziną. Życie z takim człowiekiem jest trudne. Chociaż hikikomori z reguły zachowuje się spokojnie, to nieraz

38 A. Leszczyńska, Powrotność skazanych do zakładów karnych, „Przegląd Więziennictwa Polskiego" 2017, nr 96, s. 63.

${ }^{39}$ J.K. Puchalska, dz. cyt., s. 159-162. 
może wpaść w szał. Szczególnie broniąc swego azylu, na przykład przed sprzątaniem. Potrafi też szantażować rodzinę swoim życiem i zdrowiem ${ }^{40}$.

Jak już wcześniej pisaliśmy, przyczyn tego stanu rzeczy należy upatrywać w bezpośrednim otoczeniu osoby wycofanej. Rodzice często nie potrafią przygotować swoich dzieci do nowych realiów społecznych i gospodarczych, a presja wywierana na dziecko wynika częstokroć z ich własnych, niespełnionych ambicji ${ }^{41}$. Tymczasem gdy życie społeczne nabiera tempa, nie każdy potrafi sobie z tym poradzić i niekiedy zaczyna się wycofywać. Skutkiem mogą być między innymi zaburzenia snu, wahania nastroju, zaburzenia lękowe, depresja czy też nadużywanie różnych substancji.

Problem ten został nakreślony przez Jana Komasę w Sali samobójców. Film ten zobrazował sytuację, gdzie rodzice, zajęci swoimi sprawami, zamiast wsparcia dają dziecku technologię, nie kontrolując, w jaki sposób ono z niej korzysta.

Szczególną uwagę na obecność technologii w wychowaniu powinni zwrócić rodzice dzieci młodszych. Zdaniem niektórych psychologów dzieci do 2.-3. roku życia w ogóle nie powinny dotykać komputera czy telefonu, a starsze - w ograniczonym zakresie. Problem ten dostrzeżono również w raporcie pt. Edukacja zdalna: co się stato z uczniami, ich rodzicami i nauczycielami?. Autorzy raportu w zaleceniach piszą, iż konieczne jest „wypracowanie jasnych wytycznych dotyczących czasu spędzanego przed ekranem przez uczniów i nauczycieli w związku z realizacją zdalnej edukacji. Zalecenia te powinny być dostosowane do wieku uczniów oraz uwzględniać dzienny i tygodniowy plan lekcji oraz ich charakter. W czasie zdalnej edukacji, podczas której jej uczestnicy narażeni są na intensywny kontakt $z$ urządzeniami ekranowymi, szczególnego znaczenia nabierają te przedmioty, które z powodzeniem mogą być realizowane przy minimalnym wykorzystaniu internetu, jak wychowanie fizyczne czy zajęcia plastyczne. Należy unikać sytuacji, w której lekcje prowadzone są online w proporcji 1:1, ponieważ skutkuje to spędzeniem kilku godzin dziennie przed ekranem nawet przez najmłodszych uczniów. Konieczne jest wprowadzenie systemowych rozwiązań w zakresie higieny cyfrowej uczniów, rodziców i nauczycieli jako stałego i niezbędnego elementu edukacji cyfrowej społeczeństwa informacyjnego. Rozwiązania te wspierają odpowiedzialne korzystanie z nowych technologii, sprzyjają rozwojowi i pozwalają uniknąć negatywnych konsekwencji niewłaściwego używania urządzeń cyfrowych nie tylko w czasie zdalnej edukacji, ale także poza nią. Edukacja ta powinna obejmować wszystkie etapy nauczania i być dostosowana do wieku i doświadczeń odbiorców" ${ }^{42}$. Dziecko do 7.-8. roku życia rozwija bowiem swoje zdolności manualne, jest kształtowane przez dotyk i kontakt, rozwijają się jego obie półkule mózgowe.

40 Tamże, s. 158 .

41 D. Jaworska, K. Jasiński, Rola rodziców w edukacji w opiniach uczniów i nauczycieli, „Progress. Journal of Young Researchers" 2018, nr 5, s. 54-55.

${ }^{42}$ G. Ptaszek, G.D. Stunża, J. Pyżalski, M. Dębski, M. Bigaj, Edukacja zdalna: co się stało z uczniami, ich rodzicami i nauczycielami?, Gdańskie Wydawnictwo Psychologiczne, Gdańsk 2020, s. $184-185$. 
Te dzieci bardziej potrzebują kontaktu z rówieśnikami. Tak przebiegający rozwój jest największym dziedzictwem, które potem oddziałuje na rozwój intelektualny młodego człowieka. Technologia może go jednak zakłócać, prowadząc do różnego rodzaju zaburzeń, w tym wycofania społecznego ${ }^{43}$.

Wyjście z hikikomori nie jest łatwe. Na podstawie wypowiedzi wolontariuszy, którzy dążyli do otwarcia się wycofanych na świat, wiadomo, że zanim taka osoba opuści swój pokój, musi minąć nieraz kilka miesięcy mozolnej pracy, czasem pełnej jednostronnych rozmów prowadzonych na próżno. Podstawą pracy z takimi pacjentami jest psychoterapia mająca na celu nauczenie ich wychodzenia ze swej samotni. Gdy terapeuta zostanie już wpuszczony do pokoju wycofanej osoby, zaczyna budowanie z nią relacji. Pokazuje świat zewnętrzny w taki sposób, żeby był ciekawszy od świata wirtualnego. Jeżeli ta praca zakończy się sukcesem, a więc wyjściem pacjenta $\mathrm{z}$ pokoju, to jest on namawiany do opuszczenia domu. A kiedy jest to możliwe, prowadzi się dalej terapię behawioralną w gabinecie. Na początku pacjent uczy się funkcjonować bez swojego sprzętu. Gdy już może bez niego normalnie żyć, wówczas jest uczony prawidłowych zachowań społecznych i traktowania elektroniki wyłącznie w charakterze narzędzia. Dopiero po owocnym przejściu tego etapu powraca do szkoły lub pracy. Ciężkie przypadki trafiają natomiast do ośrodka terapeutycznego, gdzie od podstaw uczą się normalnie funkcjonować w społeczeństwie. Niestety nie wszyscy hikikomori będą mogli przystosować się do normalnego życia w społeczeństwie. Aż $27 \%$ z nich nie będzie potrafiło opuścić swojego pokoju ${ }^{44}$, a część z nich po przebrnięciu przez terapię powróci do swojego azylu.

Walki z syndromem wycofania społecznego nie ułatwia nowe zagrożenie na skalę światową. Mowa tu o wirusie Sars-Cov-2 będącego przyczyną wybuchu pandemii Covid-19 z końca 2019 roku. Przez ostatni rok głównymi sposobami walki z tym schorzeniem są dystans społeczny oraz izolacja ${ }^{45}$. W związku z coraz wyższą zachorowalnością kolejne kraje wprowadzały dodatkowe ograniczenia: zamykane były szkoły, kina, teatry, restauracje i wiele innych. W obawie przed zachorowaniem ludzie przestali niemal całkowicie opuszczać swe domy. Pracują, kupują i uczą się zdalnie. Nawet sprawy bankowe czy urzędowe załatwiane są zdalnie - bez fizycznego kontaktu z drugim człowiekiem. To sprawiło, że pandemia Covid-19 stała się katalizatorem wszelkiego rodzaju traum, zaburzeń i lęków pozostających z nią w bezpośrednim związku przyczynowo-skutkowym. Pojawiające się problemy psychiczne w większości przejawiają się niepokojem, paniką i zaburzeniami obsesyjnymi związanymi z zaleceniami dezynfekcji, dy-

${ }^{43}$ L. Pawelec, Dziecko $w$ wieku przedszkolnym jako użytkownik urządzeń mobilnych (telefon, tablet, smartfon), „Acta Scientifica Academiae Ostroviensis” 2017, nr 10(2), s. 11-12.

44 T. Ogino, Managing Categorization and Social Withdrawal in Japan: Rehabilitation Process in a Private Support Group for Hikikomorians, "International Journal of Japanese Sociology" 2004, nr 13, s. 128.

45 Aktualne zasady i ograniczenia, gov.pl, Serwis Rzeczypospolitej Polskiej, 2021, https://www. gov.pl/web/koronawirus/aktualne-zasady-i-ograniczenia [dostęp: 18.02.2021]. 
stansu społecznego i izolacji ${ }^{46}$. Mogą przybierać formę przesadzoną i szkodliwą, choć u części społeczeństwa mogą w ogóle nie wystąpić żadne objawy. Przeważająca część społeczeństwa poradzi sobie sama, korzystając z wrodzonych zdolności do radzenia sobie w trudnych okolicznościach ${ }^{47}$. Pozostaje jednak niewielki odsetek ludzi, u których powszechna izolacja doprowadzi do zachowań objawiających się wycofaniem społecznym lub pogłębiających stan psychiczny będący przyczyną hikikomori.

Należy pamiętać, iż strach staje się problemem, dopiero gdy przybiera postać destrukcyjną. Normalnie jest mechanizmem obronnym, który stanowi niezbędne narzędzie do walki z zagrożeniem, również w trakcie pandemii ${ }^{48}$. Podobne znaczenie mają zachowania unikowe, które pełnią rolę przystosowawczą. Jednak w połączeniu z lękami społecznymi mogą stanowić podstawę do rozwoju takich przypadłości, jak zespół lęku uogólnionego, depresja czy dystymia. Według Tamakiego Saitõ odczuwanie lęków społecznych o znacznym natężeniu jest jednym $\mathrm{z}$ istotnych objawów pozwalających na prawidłowe rozpoznanie hikikomori. Sam syndrom wycofania społecznego jest niełatwy do zdiagnozowania. Bez dokładnego wywiadu psychologicznego jest niezwykle trudno za pomocą samego badania czy też ankiety potwierdzić lub wykluczyć hikikomori. Natomiast poziom natężenia lęków społecznych i związanych z nimi zachowań unikowych można zdiagnozować przy pomocy badania określanego jako skala lęków społecznych Liebowitza (The Liebowitz Social Axiety Scale - LSAS) ${ }^{49}$.

Właśnie to badanie było podstawą do określenia poziomu lęków społecznych w grupie badanej. Badanie to zapoczątkowane zostało w trakcie realizacji wcześniej wspomnianego projektu studenckiego ${ }^{50}$, a kontynuowane było na potrzeby niniejszego artykułu. Badanie ilościowe zostało przeprowadzone w okresie od 5 stycznia 2021 roku do 18 lutego 2021 roku za pomocą anonimowej ankiety dostępnej online na stronie projektu. W badaniu brano pod uwagę odpowiedzi każdej osoby, która udzieliła kompletu wymaganych odpowiedzi. Celem badania było uzyskanie odpowiedzi na pytanie, jaki odsetek badanych przejawia objawy fobii społecznych na poziomie wyższym od umiarkowanego. Odpowiedź na to pytanie pozwala określić częstotliwość występowania jednego z ważniejszych symptomów hikikomori. Ankieta złożona była z dwóch części. Każda z nich dotyczyła dwudziestu czterech hipotetycznych sytuacji, z którymi mogły zetknąć się badane osoby. Sytuacje wymienione $\mathrm{w}$ ankiecie to:

1. Wygłaszanie mowy lub inna aktywność przed dowolną publicznością.

2. Wygłaszanie przygotowanego wykładu lub raportu przed grupą osób.

46 J. Heitzman, dz. cyt., s. 189.

47 Tamże, s. 197.

48 A. Florczak, Mechanizmy i problemy psychosfery i somatosfery bezpieczeństwa zdrowotnego, „Desecuritate” 2015, nr 1(1), s. 65.

${ }^{49}$ M.R. Liebowitz, Social Phobia, "Modern Problems of Pharmacopsychiatry" 1987, No. 22, s. $141-173$.

${ }^{50}$ K. Ostrowska, W. Gieros, M. Dubieniecki, A. Pośpiech, J. Ratajczyk, R. Dominiak, dz. cyt. 
3. Przemawianie na spotkaniu.

4. Rozmowa ze zwierzchnikiem lub kimś ważnym.

5. Wykonywanie jakiegoś testu wiedzy lub umiejętności.

6. Praca, gdy jest się obserwowanym/obserwowaną.

7. Podrywanie kogoś.

8. Znajdowanie się w centrum zainteresowania.

9. Dzwonienie do osoby, której dobrze się nie zna.

10. Reklamowanie towaru w sklepie.

11. Spieranie się z osobą, której dobrze się nie zna.

12. Rozmowa z ludźmi, których zbyt dobrze się nie zna.

13. Pisanie, gdy jest się obserwowanym/obserwowaną.

14. Spotykanie nieznajomych osób.

15. Rozmowa telefoniczna przy innych ludziach.

16. Patrzenie w oczy obcym ludziom.

17. Korzystanie z publicznego WC.

18. Urządzanie przyjęcia.

19. Wchodzenie do pomieszczenia, gdzie już przebywają inne osoby.

20. Opieranie się natrętnemu sprzedawcy.

21. Spożywanie napojów wraz z innymi ludźmi w miejscu publicznym.

22. Wyjście na imprezę lub spotkanie towarzyskie.

23. Przebywanie w małej grupie osób.

24. Jedzenie w miejscu publicznym ${ }^{51}$.

W pierwszej części ankietowani określali wielkość swojego stresu związanego z wykonywaniem omawianej czynności, obrazując natężenie strachu w konfrontacji $\mathrm{z}$ daną sytuacją. W drugiej części badania ankietowani określali poziom zachowań unikowych, czyli chęć uchylenia się od wspomnianej czynności. Odpowiedzi na zadane pytania udzieliło 101 osób w grupie wiekowej 17-52 lata. Wyniki ankiety prezentują się następująco:

- brak oznak fobii - 59 osób $(58,42 \%)$,

- łagodna fobia społeczna - 17 osób (16,83\%),

- umiarkowana fobia społeczna - 11 osób (10,89\%),

- nasilona fobia społeczna - 11 osób (10,89\%),

- bardzo nasilona fobia społeczna - 3 osoby (2,97\%).

Szczegółowe wyniki ${ }^{52}$ sugerują, iż ankietowanych najbardziej przerażają sytuacje, w których znajdują się w centrum zainteresowania. W mniejszym stopniu obawiają się sytuacji, które nie zapewniają im pełnej kontroli nad przebiegiem wydarzeń. Minimalne obawy wiązano z sytuacjami „na własnym podwórku”, gdzie ankietowani mieli możliwość kontrolowania przebiegu wydarzeń. W pełni bezstresowo podchodzono

51 M.R. Liebowitz, dz. cyt., s. 141-173.

${ }^{52}$ K. Ostrowska, W. Gieros, M. Dubieniecki, A. Pośpiech, J. Ratajczyk, R. Dominiak, dz. cyt. 
do sytuacji komfortowych czy też takich, które wymagały zaspokojenia podstawowych potrzeb typu jedzenie czy picie. Wyniki te pokrywają się z uwarunkowaniami psychospołecznymi człowieka i jego instynktem samozachowawczym: najbardziej boimy się takich zagrożeń, które gwarantują porażkę, a wraz ze spadkiem potencjalnego zagrożenia nasz komfort psychiczny rośnie. Powyższy wniosek ma istotne znaczenie w rozpoznaniu syndromu wycofania społecznego, gdyż fobie społeczne wraz z zachowaniami unikowymi są jednym z elementów pozwalających na postawienie prawidłowej diagnozy. Niestety w przypadku powyższego badania należy wziąć pod uwagę fakt, że badaniem objęto niewielką liczbę osób, dlatego uzyskane wyniki mogą nie mieć (choć niekoniecznie) pokrycia w przypadku badania przeprowadzonego na większej społeczności.

W naszej ocenie mamy obecnie nową erę chorób, które coraz częściej dotykają młodych ludzi. Oprócz traum pandemicznych, porównywanych z syndromem stresu urazowego, pojawia się między innymi wycofanie społeczne. W obliczu izolacji pandemicznej nasuwa się wniosek, że tego typu problemy będą występować coraz częściej i coraz więcej osób będzie potrzebowało wsparcia - nie tylko fizycznego, ale przede wszystkim psychologicznego ${ }^{53}$. Chociaż z jednej strony internet jest nieodzowną formą komunikacji w dzisiejszym świecie, to z drugiej ułatwia chowanie się za komputerem. Młodzi ludzie coraz częściej spotykają się na portalach internetowych i coraz rzadziej wychodzą z domów. Dziś nie widać dzieci ani młodzieży bawiących się, spędzających z rówieśnikami czas na podwórku. Do tego przedłużająca się izolacja potęguje strach przed otoczeniem, utrudniając dzieciom i nastolatkom nawiązywanie prawidłowych relacji międzyludzkich. Relacji, których nie sposób zbudować w świecie wirtualnym. Dlatego tak ważne jest, aby odpowiednio zadbać o zapewnienie właściwego poziomu komfortu psychicznego i minimalizować obciążenie psychiczne. „Istotna jest także troska o zdrowie psychiczne uczniów, która powinna oznaczać udzielanie wsparcia społecznego uczniom oraz w wymagających tego przypadkach udzielanie pomocy profesjonalnej ze strony odpowiednich osób i instytucji (lekarze, psychologowie, pomoc społeczna, policja, sąd). W wielu przypadkach pomoc taka obejmować musi nie tylko samych uczniów, ale także ich rodziny. Szczególna troska powinna dotyczyć uczniów, których relacje domowe w warunkach izolacji pogarszają się. Takich uczniów, oceniających, że relacje pogorszyły się, którzy byli skazani na ciągłe przebywanie z rodzicami i opiekunami, było $13 \%$. To właśnie na nich wszelkie problemy związane z pogarszającymi się relacjami mogły bardziej negatywnie wpływać" 54 . W takiej sytuacji żadna z potrzeb psychicznych nie może być zaniedbana, gdyż ich marginalizowanie może powodować nasilające się problemy psychiczne ujawniające się nawet kilka lat po ustaniu stanu zagrożenia wywołanego przez pandemię $e^{55}$.

\footnotetext{
${ }^{53}$ G. Ptaszek, G.D. Stunża, J. Pyżalski, M. Dębski, M. Bigaj, dz. cyt., s. 188.

${ }^{54}$ Tamże, s. 186.

${ }^{55}$ J. Heitzman, dz. cyt., s. 194.
} 


\section{Bibliografia}

Aktualne zasady i ograniczenia, gov.pl, Serwis Rzeczypospolitej Polskiej, 2021, https:// www.gov.pl/web/koronawirus/aktualne-zasady-i-ograniczenia [dostęp: 18.02.2021].

Doi T., Amae: A Key Concept for Understanding Japanese Personality Structure, [w:] R.K. Beardsley, R.J. Smith (red.), Japanese Culture. Its Development and Characteristics, Methuen \& Company, Londyn 2004.

Florczak A., Mechanizmy i problemy psychosfery i somatosfery bezpieczeństwa zdrowotnego, „Desecuritate” 2015, nr 1(1).

Fromm E., O sztuce miłości, Dom Wydawniczy Rebis, Poznań 2013.

Heitzman J., Wpływ pandemii COVID-19 na zdrowie psychiczne, „Psychiatria Polska” 2020, nr 2(54).

Jaworska D., Jasiński K., Rola rodziców w edukacji w opiniach uczniów i nauczycieli, „Progress. Journal of Young Researchers” 2018, nr 5.

Kalita K., Psychospołeczne wymiary „wycofania społecznego” na przykładzie Japonii, „Zeszyty Naukowe WSOWL” 2013, nr 1(167).

Kawakami N., Umeda M., Association of childhood family environments with the risk of social withdrawal (hikikomori) in the community population in Japan, "Psychiatry and Clinical Neurosciences" 2012, No. 66(2).

Krzystanek M., Hikikomori. Dzieci internetu, „Psychiatra. Pismo dla praktyków” 2020, nr 1(28).

Leszczyńska A., Powrotność skazanych do zakładów karnych, „Przegląd Więziennictwa Polskiego" 2017, nr 96.

Liebowitz M.R., Social Phobia, "Modern Problems of Pharmacopsychiatry” 1987, No. 22.

Miksza W., Teatr jednego aktora i czterech ścian, „Interdyscyplinarne Konteksty Pedagogiki Specjalnej” 2013, nr 2.

Ogino T., Managing Categorization and Social Withdrawal in Japan: Rehabilitation Process in a Private Support Group for Hikikomorians, "International Journal of Japanese Sociology" 2004, nr 13.

Orzechowski R., Analiza dysfunkcji występujacych w rodzinie japońskiej na przykładzie hikikomori i syndromu męża na emeryturze (RHS), „Tematy z Szewskiej” 2017, nr 2(19).

Ostrowska K., Gieros W., Dubieniecki M., Pośpiech A., Ratajczyk J., Dominiak R., Samotność: stary problem - nowe ofiary, 2021, Samotność: stary problem - nowe ofiary. - Ankieta „leki społeczne” (google.com) [dostęp: 23.07.2021].

Pawelec L., Dziecko w wieku przedszkolnym jako użytkownik urządzeń mobilnych (telefon, tablet, smartfon), „Acta Scientifica Academiae Ostroviensis” 2017, nr 10(2).

Ptaszek G., Stunża G.D., Pyżalski J., Dębski M., Bigaj M., Edukacja zdalna: co się stało z uczniami, ich rodzicami i nauczycielami?, Gdańskie Wydawnictwo Psychologiczne, Gdańsk 2020. 
Puchalska J.K., Hikikomori - więzień z wyboru, „Maska - magazyn antropologiczno-społeczno-kulturowy" 2010, nr 9.

Rydz S., Psychologiczne skutki samotnego rodzicielstwa, [w:] I. Janicka (red.), Rodzice $i$ dzieci w różnych systemach rodzinnych, Oficyna Wydawnicza „Impuls”, Kraków 2010.

Saitõ T., Hikikomori. Adolescence without End, University of Minnesota Press, Minneapolis 2013.

Sarnowski P., Wirus samotności i wyobcowania, Sarnowski Behawioralnie, 2018, https: //sarnowskibehawioralnie.wordpress.com/2018/03/02/hikikomori/ [dostęp: 23.07.2021].

Splisgart J., Przemiany modelu rodziny a sytuacja ludzi starszych w Japonii u progu XXI wieku, „Gdańskie Studia Azji Wschodniej” 2017, nr 11.

Swędrak J., Model życia wspótczesnej rodziny, „Paedagogia Christiana” 2007, nr 2(20). Szluz B., „Hikikomori” - o problemie wycofania społecznego młodych ludzi, „Seminare” 2018, nr 1(39).

Wasilewska-Ostrowska K., Młodzież wobec samotności wświetle badań porównawczych, „Kultura i Wychowanie” 2014, nr 8(2).

Wisłocka M., Sztuka kochania, Wydawnictwo Agora, Warszawa 2016.

\section{Social withdrawal in the era of the Covid-19 pandemic: an old problem - new victims}

Abstract: Hikikomori, or social withdrawal syndrome, is an old problem that has become more acute in the wake of the Covid-19 pandemic. Widespread isolation, remote learning, and social distancing are some of the factors that increase the chances of hikikomori development. The article describes the genesis of social withdrawal, its possible causes, including the influence of technology and family relationships on the formation of hikikomori. The study of social anxiety, the concentration of which is one of the symptoms of social withdrawal, will also be discussed.

Keywords: hikikomori, Covid-19, loneliness, Poland, Japan, family, feelings

\section{About the Authors}

Piotr Sarnowski - M.A., certified specialist in addiction and co-addiction psychotherapy, group trainer, rehabilitation educator. He works with the method of psychodrama and system settings. Former chairman of the committee for solving alcohol problems in Milanówek. Former lecturer at the Cardinal Stefan Wyszyński University in Warsaw. He works with the disabled and homeless. Nominated for the semi-finals of the 17th edition of the "Man Without Borders" competition (2019) for selfless work for others. He is currently writing his doctoral dissertation. 
Rafał Dominiak - a pharmaceutical technician with fifteen years of experience; has a range of pharmaceutical training certificates, incl. in the handling of difficult patients. City guard since 2020. Student of the Academy of Humanities and Economics in Łódź major in internal security. Interests: psychology, genealogy, sociology. At the moment, without significant academic achievements, but always curious about the world and constantly searching. 